\title{
Actinobacteria as Promising Candidate for Polylactic Acid Type Bioplastic Degradation
}

\author{
Natthicha Butbunchu ${ }^{1,2}$ and Wasu Pathom-Aree ${ }^{3,4 *}$ \\ ${ }^{1}$ Master of Science Program in Applied Microbiology (International Program), Faculty of Science, Chiang Mai University, \\ Chiang Mai, Thailand, ${ }^{2}$ Graduate School, Chiang Mai University, Chiang Mai, Thailand, ${ }^{3}$ Department of Biology, Faculty \\ of Science, Chiang Mai University, Chiang Mai, Thailand, ${ }^{4}$ Center of Excellence in Microbial Diversity and Sustainable \\ Utilization, Faculty of Science, Chiang Mai University, Chiang Mai, Thailand
}

Polylactic acid (PLA) is one of the most commercially available and exploited bioplastics worldwide. It is an important renewable polymer for the replacement of petroleumbased plastic materials. They are both biodegradable and bio-based plastic. Microbial degrading activity is a desirable method for environmental safety and economic value for bioplastic waste managements. Members of the phylum actinobacteria are found to play an important role in PLA degradation. Most of the PLA degrading actinobacteria belong to the family Pseudonocardiaceae. Other taxa include members of the family Micromonosporaceae, Streptomycetaceae, Streptosporangiaceae, and Thermomonosporaceae. This mini-review aims to provide an overview on PLA degrading actinobacteria including their diversity and taxonomy, isolation and screening procedures and PLA degrading enzyme production from 1997 to 2019. Consideration is also given to where to sampling and how we might use these beneficial actinobacteria for PLA waste management.

Keywords: actinobacteria, polylactic acid, biodegradation, PLA-degrading enzyme, serine protease, bioplastic

\section{INTRODUCTION}

Plastics are polymeric materials widely used globally with an important role in everyday life. Increasing demand promotes global plastic market to grow continuously (Mekonnen et al., 2013; Geyer et al., 2017). Conventional petroleum-derived plastics such as polyethylene terephthalate, PET are commonly used as single-use packaging which caused environmental problems from their resistant to degradation. Over the past few decades, awareness on our dependence on limited oil supply has been increased. These have inspired researchers all over the world to search for alternative renewable plastics. Eventually, bioplastics have been successfully developed (Vink et al., 2003 , 2004). Bioplastics are large family of different materials. The word "bio-plastics" refers to either biodegradable plastics, bio-based plastics or features both properties (Tokiwa et al., 2009; Alshehrei, 2017). Bio-based is the term for material partly derived from renewable resources, while bio-degradable is a chemical process during which available microorganisms in the environments convert materials into natural substances (de Wilde, 2009; Song et al., 2009, 2011). Recently, there are bioplastic alternatives for almost all conventional plastics. Among currently available bioplastics, poly(lactic acid) (PLA) is one of the bio-based and biodegradable plastic of great commercial value (Karan et al., 2019). It is an aliphatic polyester manufactured by ring-opening polymerization of lactide or by polycondensation of lactic acid monomers derived from the fermentation of starch as a feedstock (Garlotta, 2001; Calabia et al., 2010; Karamanlioglu et al., 2017). PLA exhibited many excellent properties such as thermoplastics, gas barrier, UV resistant, elastic, rigid, hydrophobic, and biocompatible tissue (Farrington et al., 2005; Carosio et al., 2014; 
Scarfato et al., 2015; Farah et al., 2016). Therefore, it can be used for various applications such as food packaging and fiber suitable for technical textile application. Moreover, PLA has been used extensively in the medical field due to their ability to be incorporated into human and animal bodies as medical implants, drug delivery materials, and surgical sutures (Jalil, 1990; Ikada and Tsuji, 2000; Ahmed et al., 2018). Biodegradability of PLA is a critical consideration for the development of suitable biological treatments for waste management. A number of microorganisms and their enzymes are involved in biodegradation process especially, bacteria and filamentous fungi (Williams, 1981; Torres et al., 1996; Jarerat and Tokiwa, 2001; Kim et al., 2008; Szumigaj et al., 2008; Bubpachat et al., 2018). Actinobacteria are the first bacteria that found to degrade PLA (Pranamuda et al., 1997). This discovery opened up a view on actinobacteria as potential PLA degrading microorganisms.

\section{DIVERSITY OF PLA-DEGRADING ACTINOBACTERIA: HOW TO FIND AND WHERE TO LOOK?}

Polylactic acid-degrading ability in microorganisms are not widely distributed as PLA degraders are less discovered than other types of plastic degrading microorganisms (Nishida and Tokiwa, 1993; Pranamuda et al., 1997; Suyama et al., 1998; Tokiwa et al., 2009). Actinobacteria are among the few microorganisms with potential for PLA degradation (Jarerat et al., 2002, 2003; Sukkhum et al., 2009a,b, 2011, 2012; Chomchoei et al., 2011; Konkit et al., 2012; Penkhrue et al., 2015, 2018; Panyachanakul et al., 2017, 2019). PLA-degrading actinobacteria are affiliated with 26 species in 11 genera namely Actinomadura, Amycolatopsis, Kibdelosporangium, Micromonospora, Nonomuraea, Pseudonocardia, Saccharothrix, Streptoalloteichus, Streptomyces, Thermomonospora, and Thermopolyspora (Table 1).

The most dominant PLA degrading actinobacteria are members of the genus Amycolatopsis namely Amycolatopsis sp. HT-32 (Pranamuda et al., 1997), Amycolatopsis sp. 3118 (Ikura and Kudo, 1999), Amycolatopsis sp. KT-s-9 (Tokiwa et al., 1999), Amycolatopsis mediterranei ATCC 27649 (Pranamuda and Tokiwa, 1999), Amycolatopsis sp. 41 (Pranamuda et al., 2001), Amycolatopsis sp. K104-1 (Nakamura et al., 2001), Amycolatopsis orientalis ssp. orientalis ( $\mathrm{Li}$ et al., 2008), Amycolatopsis thailandensis CMU-PLA07 ${ }^{\mathrm{T}}$ (Chomchoei et al., 2011), and Amycolatopsis sp. SCM_MK2-4 (Penkhrue et al., 2015). Members of the genus Amycolatopsis are well known producers of secondary metabolites which can be exploited for biotechnological applications (Tan and Goodfellow, 2015; Sangal et al., 2018). Amycolatopsis species are commonly found in arid or hyper-arid soils (Tan and Goodfellow, 2015) as exemplified by the description of recent novel Amycolatopsis from desert soils (Busarakam et al., 2016; Idris et al., 2018). However, these sources have been explored only for bioactive compounds producing Amycolatopsis. We opine that arid and hyper-arid environments might harbor diverse Amycolatopsis strains with potential PLA degrading properties.
Recently, research on PLA-degrading actinobacteria is focus on the mechanisms of degradation and their enzymatic role. The success of such studies relies on the ability to obtain these PLA-degraders in pure culture under laboratory conditions. In general, there are three approaches for the selective isolation of PLA degrading actinobacteria from environmental samples. The first approach is a simple direct isolation from the samples. Environmental samples are taken, prepared for an appropriate serial dilution and spread directly on emulsified PLA agar. After incubation at suitable temperature, plates were observed for the clear zone around colonies as an indicator for PLA degradation. For instance, the first PLA degrading actinobacterium in the family Pseudonocardiaceae, Amycolatopsis sp. HT-32 was isolated from soil samples and reported to form clear zone around colonies on emulsified PLA plate within 14 days (Pranamuda et al., 1997). Many PLA degrading actinobacteria were isolated from various environmental samples by dilution spread plate on emulsified PLA agar using this approach including a novel species, Amycolatopsis oliviviridis (Table 1). This direct isolation plate assay using emulsified PLA provides a convenient and easy way for screening large numbers of isolates for PLA degraders.

The second approach involves repeated adaptation and selection procedures. In this approach, basal agar plates were seeded with samples then, overlaid with PLA film. Colonies growing and appearing on the PLA films were selected and cultured in $10 \mathrm{~mL}$ basal medium containing $0.2 \%(\mathrm{w} / \mathrm{v})$ PLA film at $30^{\circ} \mathrm{C}$ for 8 weeks to observe PLA degradation (Ikura and Kudo, 1999). The strains that decreased the film weight by more than $5.5 \%$ were transferred to a new liquid medium and incubated at $30^{\circ} \mathrm{C}$ and $37^{\circ} \mathrm{C}$ for 4 weeks, and strains that efficiently decreased the film weight were isolated. This method allows adaptation of actinobacteria to PLA degradation as PLA is a synthetic polymer generally not available in nature. Highly efficient PLA-degrading strains could be obtained by this adaptation approach as exemplified in the recent report on the degradation of PLA packaging by Streptomyces sp. KKU215 (Yottakot and Leelavatcharamas, 2019).

The third approach involved an enrichment step. Enrichment method is a very useful microbiological tool which is used to support the growth of interested microbes and to increase their small number in environmental samples to detectable levels (Pham and Kim, 2012). Briefly, a soil sample is cultured in a basal medium containing $0.1 \%$ (w/v) PLA film before the sampleenriched culture broth was spread onto the emulsified PLA agar. Novel actinobacteria, Amycolatopsis thailandensis CMU-PLA07 ${ }^{\mathrm{T}}$ has been successfully isolated from natural park soil sample in northern Thailand using this approach (Chomchoei et al., 2011).

Over the past two decades, researchers have relied on conventional isolation methods to search for PLA degrading microorganisms in particular actinobacteria. However, it is well accepted that only a small fraction (approximately 1\%) of bacteria exists in nature can be grown in the laboratory (Pham and Kim, 2012; Stewart, 2012). Modern molecular biological techniques provide a powerful tool to explore diversity of PLA degrading microorganisms in the environments. Most available techniques involve the analysis of nucleic acids extracted directly from the environments to study microbial diversity, thus avoid limitations 
TABLE 1 | List of PLA-degrading actinobacteria, their degrading enzymes and degradation detection methods from 1997 to 2019.

\begin{tabular}{|c|c|c|c|c|c|c|c|c|}
\hline Family & Genus & Species/strain & Sample sources & Isolation medium & Isolation method & $\begin{array}{l}\text { Degradation } \\
\text { detection method }\end{array}$ & Enzyme type & References \\
\hline \multirow[t]{2}{*}{ Micromonosporaceae } & Micromonospora & $\begin{array}{l}\text { Micromonospora } \\
\text { echinospora B12-1 }\end{array}$ & Soil & $\begin{array}{l}\text { Emulsified PLA } \\
\text { agar }\end{array}$ & $\begin{array}{l}\text { Plate count and } \\
\text { clear zone }\end{array}$ & Turbidity method & - & $\begin{array}{l}\text { Sukkhum et al., } \\
2009 \mathrm{~b}\end{array}$ \\
\hline & & $\begin{array}{l}\text { Micromonospora } \\
\text { viridifaciens B7-3 }\end{array}$ & Soil & $\begin{array}{l}\text { Emulsified PLA } \\
\text { agar }\end{array}$ & $\begin{array}{l}\text { Plate count and } \\
\text { clear zone }\end{array}$ & Turbidity method & - & $\begin{array}{l}\text { Sukkhum et al., } \\
2009 \mathrm{~b}\end{array}$ \\
\hline \multirow[t]{12}{*}{ Pseudonocardiaceae } & Amycolatopsis & $\begin{array}{l}\text { Amycolatopsis sp. } \\
\text { HT-32 }\end{array}$ & $\begin{array}{l}\text { Soil form paddy } \\
\text { fields, weed fields, } \\
\text { roadsides, and } \\
\text { dumping grounds }\end{array}$ & $\begin{array}{l}0.1 \%(w / v) \\
\text { emulsified PLA }\end{array}$ & $\begin{array}{l}\text { Plate count and } \\
\text { clear zone }\end{array}$ & $\begin{array}{l}\text { Film-weight loss; } \\
\text { monomer } \\
\text { production }\end{array}$ & Protease & $\begin{array}{l}\text { Pranamuda et al., } \\
1997\end{array}$ \\
\hline & & $\begin{array}{l}\text { Amycolatopsis } \\
3118\end{array}$ & Not specified & Basal medium & $\begin{array}{l}\text { Plate count and } \\
\text { clear zone }\end{array}$ & $\begin{array}{l}\text { Film-weight loss; } \\
\text { monomer } \\
\text { production }\end{array}$ & Protease & $\begin{array}{l}\text { Ikura and Kudo, } \\
1999\end{array}$ \\
\hline & & $\begin{array}{l}\text { Amycolatopsis sp. } \\
\text { KT-s-9 }\end{array}$ & Not specified & $\begin{array}{l}\text { PLLA emulsified } \\
\text { and silk plates }\end{array}$ & $\begin{array}{l}\text { Plate count and } \\
\text { clear zone }\end{array}$ & - & Protease & Tokiwa et al., 1999 \\
\hline & & $\begin{array}{l}\text { Amycolatopsis } \\
\text { mediterranei ATCC } \\
27649\end{array}$ & Not specified & - & - & Clear zone method & - & $\begin{array}{l}\text { Pranamuda and } \\
\text { Tokiwa, } 1999\end{array}$ \\
\hline & & $\begin{array}{l}\text { Amycolatopsis sp. } \\
41\end{array}$ & Not specified & $\begin{array}{l}\text { Emulsified PLA } \\
\text { agar }\end{array}$ & $\begin{array}{l}\text { Plate count and } \\
\text { clear zone }\end{array}$ & $\begin{array}{l}\text { Film-weight loss; } \\
\text { monomer } \\
\text { production }\end{array}$ & Protease & $\begin{array}{l}\text { Pranamuda et al., } \\
2001\end{array}$ \\
\hline & & $\begin{array}{l}\text { Amycolatopsis sp. } \\
\text { K104-1 }\end{array}$ & Soil & $\begin{array}{l}0.1 \% \text { emulsified } \\
\text { PLLA }\end{array}$ & $\begin{array}{l}\text { Plate count and } \\
\text { clear zone }\end{array}$ & Turbidity method & Serine protease & $\begin{array}{l}\text { Nakamura et al., } \\
2001\end{array}$ \\
\hline & & $\begin{array}{l}\text { Amycolatopsis } \\
\text { orientalis ssp. } \\
\text { orientalis }\end{array}$ & **IFO 12362 & - & - & Film-weight loss & Serine protease & Li et al., 2008 \\
\hline & & $\begin{array}{l}\text { Amycolatopsis } \\
\text { thailandensis } \\
\text { CMU-PLA07 }^{\top}\end{array}$ & Natural park soil & $\begin{array}{l}\text { Basal medium with } \\
\text { PLA film }\end{array}$ & $\begin{array}{l}\text { Plate count and } \\
\text { clear zone }\end{array}$ & - & - & $\begin{array}{l}\text { Chomchoei et al., } \\
2011\end{array}$ \\
\hline & & $\begin{array}{l}\text { Amycolatopsis } \\
\text { oliviviridis } \\
\text { SCM_MK2-4 }\end{array}$ & Agricultural soils & $\begin{array}{l}\text { Emulsified PLA } \\
\text { agar }\end{array}$ & $\begin{array}{l}\text { Plate count and } \\
\text { clear zone }\end{array}$ & Turbidity method & $\begin{array}{l}\text { Protease, } \\
\text { esterase and } \\
\text { lipase }\end{array}$ & $\begin{array}{l}\text { Penkhrue et al., } \\
\text { 2015, } 2018\end{array}$ \\
\hline & Saccharothrix & $\begin{array}{l}\text { Saccharothrix } \\
\text { (Lentzea) } \\
\text { waywayandensis }\end{array}$ & *JCM 9114 & - & - & $\begin{array}{l}\text { Film-weight loss; } \\
\text { monomer } \\
\text { production }\end{array}$ & Protease & $\begin{array}{l}\text { Jarerat and Tokiwa, } \\
\text { 2003; Nair et al., } \\
2012\end{array}$ \\
\hline & Kibdelosporangium & $\begin{array}{l}\text { Kibdelosporangium } \\
\text { aridum }\end{array}$ & *JCM 7912 & - & - & $\begin{array}{l}\text { Film-weight loss; } \\
\text { monomer } \\
\text { production }\end{array}$ & Protease & Jarerat et al., 2003 \\
\hline & Pseudonocardia & $\begin{array}{l}\text { Pseudonocardia } \\
\text { alni AS4.1531 }\end{array}$ & $\begin{array}{l}\text { Chinese culture } \\
\text { collection }\end{array}$ & $\begin{array}{l}\text { Basal medium with } \\
0.1 \%(\mathrm{w} / \mathrm{v}) \text { gelatin } \\
\text { and } 50 \mathrm{mg} \text { PLA } \\
\text { films }\end{array}$ & - & $\begin{array}{l}\text { Film-weight loss; } \\
\text { monomer } \\
\text { production }\end{array}$ & - & Konkit et al., 2012 \\
\hline
\end{tabular}


TABLE 1 | Continued

\begin{tabular}{|c|c|c|c|c|c|c|c|c|}
\hline Family & Genus & Species/strain & Sample sources & Isolation medium & Isolation method & $\begin{array}{l}\text { Degradation } \\
\text { detection method }\end{array}$ & Enzyme type & References \\
\hline & & $\begin{array}{l}\text { Pseudonocardia } \\
\text { sp. RM423 }\end{array}$ & $\begin{array}{l}\text { Kasetsart } \\
\text { University, Thailand }\end{array}$ & Emulsified-PLA & Clear zone & $\begin{array}{l}\text { Film-weight loss; } \\
\mathrm{CO}_{2} \text { content }\end{array}$ & - & Apinya et al., 2015 \\
\hline & Streptoalloteichus & $\begin{array}{l}\text { Streptoalloteichus } \\
\text { sp. }\end{array}$ & *JCM and **IFO & $\begin{array}{l}\text { Emulsified-PLA and } \\
\text { silk fibroin agar }\end{array}$ & $\begin{array}{l}\text { Plate count and } \\
\text { clear zone }\end{array}$ & $\begin{array}{l}\text { Total organic } \\
\text { carbon (TOC); } \\
\text { residual films in the } \\
\text { culture broth }\end{array}$ & - & Jarerat et al., 2002 \\
\hline \multirow[t]{2}{*}{ Streptomycetaceae } & Streptomyces & $\begin{array}{l}\text { Streptomyces sp. } \\
\text { APL3 }\end{array}$ & Compost soils & $\begin{array}{l}\text { Emulsified PLA } \\
\text { agar }\end{array}$ & $\begin{array}{l}\text { Plate count and } \\
\text { clear zone }\end{array}$ & - & $\begin{array}{l}\text { Serine } \\
\text { hydrolase }\end{array}$ & Sriyapai et al., 2018 \\
\hline & & $\begin{array}{l}\text { Streptomyces sp. } \\
\text { KKU215 }\end{array}$ & $\begin{array}{l}\text { Botanical garden } \\
\text { soil }\end{array}$ & $\begin{array}{l}\text { Emulsified PLA } \\
\text { agar }\end{array}$ & $\begin{array}{l}\text { Plate count and } \\
\text { clear zone }\end{array}$ & $\begin{array}{l}\text { PLA-packaging } \\
\text { weight loss and } \\
\text { surface change }\end{array}$ & - & $\begin{array}{l}\text { Yottakot and } \\
\text { Leelavatcharamas, } \\
2019\end{array}$ \\
\hline \multirow[t]{4}{*}{ Streptosporangiaceae } & Thermopolyspora & Thermopolyspora & Compost & - & $\begin{array}{l}\text { Molecular } \\
\text { technique }\end{array}$ & - & - & $\begin{array}{l}\text { Sangwan and Wu, } \\
2008\end{array}$ \\
\hline & & $\begin{array}{l}\text { Thermopolyspora } \\
\text { flexuosa FTPLA }\end{array}$ & Compost & $\begin{array}{l}\text { Mineral agar media } \\
\text { with PLA } \\
\text { suspension }\end{array}$ & $\begin{array}{l}\text { Plate count and } \\
\text { TGGE method }\end{array}$ & - & - & $\begin{array}{l}\text { Husárová et al., } \\
2014\end{array}$ \\
\hline & Nonomuraea & $\begin{array}{l}\text { Nonomuraea } \\
\text { terrinata } L 44-1\end{array}$ & Soil & $\begin{array}{l}\text { Emulsified PLA } \\
\text { agar }\end{array}$ & $\begin{array}{l}\text { Plate count and } \\
\text { clear zone }\end{array}$ & Turbidity method & - & $\begin{array}{l}\text { Sukkhum et al., } \\
2009 \mathrm{~b}\end{array}$ \\
\hline & & $\begin{array}{l}\text { Nonomuraea } \\
\text { fastidiosa T9-1 }\end{array}$ & Soil & $\begin{array}{l}\text { Emulsified PLA } \\
\text { agar }\end{array}$ & $\begin{array}{l}\text { Plate count and } \\
\text { clear zone }\end{array}$ & Turbidity method & - & $\begin{array}{l}\text { Sukkhum et al., } \\
2009 \mathrm{~b}\end{array}$ \\
\hline \multirow[t]{4}{*}{ Thermomonosporaceae } & Thermomonospora & Thermomonospora & Compost & - & $\begin{array}{l}\text { Molecular } \\
\text { technique }\end{array}$ & - & - & $\begin{array}{l}\text { Sangwan and Wu, } \\
2008\end{array}$ \\
\hline & & $\begin{array}{l}\text { Thermobifida alba } \\
\text { AHK119 }\end{array}$ & Compost & - & - & - & Cutinase & $\begin{array}{l}\text { Hu et al., 2010; } \\
\text { Kitadokoro et al., } \\
2019\end{array}$ \\
\hline & Actinomadura & $\begin{array}{l}\text { Actinomadura } \\
\text { keratinilytica T16-1 }\end{array}$ & Soil & $\begin{array}{l}\text { Emulsified PLA } \\
\text { agar }\end{array}$ & $\begin{array}{l}\text { Plate count and } \\
\text { clear zone }\end{array}$ & Turbidity method & Serine protease & $\begin{array}{l}\text { Sukkhum et al., } \\
2009 \mathrm{~b}\end{array}$ \\
\hline & & $\begin{array}{l}\text { Actinomadura sp. } \\
\text { TF1 }\end{array}$ & Compost soils & $\begin{array}{l}\text { Emulsified PLA } \\
\text { agar }\end{array}$ & $\begin{array}{l}\text { Plate count and } \\
\text { clear zone }\end{array}$ & - & $\begin{array}{l}\text { Serine } \\
\text { hydrolase }\end{array}$ & Sriyapai et al., 2018 \\
\hline
\end{tabular}

*Obtained from JCM (Japan Collection of Microorganisms); ** Obtained from IFO (Institute for Fermentation, Osaka). 
of the culture dependent approach. This culture independent approach offers a useful tool for the detection of new group of PLA degrading actinobacteria.

Additional genera of PLA-degrading actinobacteria were found from compost samples using culture independent approach (Sangwan and Wu, 2008; Sangwan et al., 2009; Husárová et al., 2014). Total genomic DNA were extracted from the prepared mixtures sample and amplified by polymerase chain reaction (PCR) of small-subunit rRNA gene sequences to compare microbial community in compost before (day 0) and after PLA degradation (days-60) (Sangwan and Wu, 2008). Members of uncultured bacterial phyla at day 0 are mixture of Actinobacteria, Bacteroidetes, Chloroflexi, Firmicutes, Gemmatimonadetes, Planctomycetes, Proteobacteria, and TM7 while Actinobacteria are dominant in day-60 sample. The majority of cloned gene sequences identified belonged to members of the phyla Actinobacteria in the genera Actinomadura, Amycolatopsis, Pseudonocardia, Salinispora, Thermomonospora, and Thermopolyspora. Actinobacteria especially those belonging to the genera Thermopolyspora and Thermomonospora, are suggested to have important roles in biodegradation of PLA under composting conditions as these two genera were subsequently isolated from the compost sample at the end of the experiment. The PLA degradation under aerobic composting was observed as a change in PLA molecular weight and polydispersity index (PDI, $\bar{M}_{\mathrm{W}} / \bar{M}_{\mathrm{n}}$ ). After 60 days of composting, the $\bar{M}_{\mathrm{n}}$ of PLA was reduced from $1.3 \times 10^{5}$ to approximately $5564 \mathrm{Da}$. The PDI comparison of PLA sample before and after 60 days of composting was slightly decreased (before composting, $\bar{M}_{\mathrm{W}} / \bar{M}_{\mathrm{n}}=1.5$; after 60 days composting, $\bar{M}_{\mathrm{W}} / \bar{M}_{\mathrm{n}}=1.1$ ) (Sangwan and Wu, 2008).

Cultivation experiment on the same day-60 compost found that most bacterial isolates selected for identification were belonged to the genera Rhizobium, Bacillus, and Tuberibacillus, with only two actinobacterial isolates belonged to the genera Thermomonospora and Thermopolyspora. The discrepancy between cultivation and molecular studies strongly suggested that culture dependent and independent approaches should be used in combination to search for new PLA degrading microorganisms from environmental samples. Similar result was reported by Husárová et al. (2014), PLA degrading bacteria identified as Thermopolyspora flexuosa FTPLA was isolated from compost and also detected by temperature gradient gel electrophoresis (TGGE) analysis. From these studies, it is evident that compost is also an interesting source for PLA degrading actinobacteria. These works highlight the importance of using novel molecular ecological techniques for in situ identification of novel microorganisms involved in biodegradation of polymeric materials in particular PLA and guided the isolation of such organisms in pure culture.

\section{ACTINOBACTERIA AS POTENTIAL PLA DEGRADER - ENZYMATIC DEGRADATION AND INDUCERS}

Polymeric materials like a poly(lactic acid) can be degraded by several microorganisms using their secreted enzymes by hydrolysis reaction (Banerjee et al., 2014). Many studies have been conducted on purification of depolymerase enzymes from PLA degrading microorganisms. Key enzymes which play an important role in depolymerization of PLA are carboxylesterase, cutinases, lipases, and serine proteases (Hajighasemi et al., 2016). Interestingly, only serine protease is identified as an important enzyme in PLA-degrading activities of actinobacteria in the genus Amycolatopsis (Tokiwa and Jarerat, 2004; Lim et al., 2005; Tokiwa and Calabia, 2006; Kawai, 2010). Serine protease usually follows a two-step reaction of hydrolysis. In the first step, PLA substrate binds to the surface of serine protease at the active site. Second step involves the cleavage of peptide-like bonds in PLA through reaction of catalytic amino acids (Ser, Asp, and His) collaborates with water (Hedstrom, 2002). However, little information on the purification and characterization of PLA degrading enzymes are available.

Purified PLA degrading enzymes have been reported from three PLA degrading Amycolatopsis. The first report dealing with the purification of a poly(L-lactic acid) degrading enzyme was purified from mesophilic actinobacteria, Amycolatopsis sp. strain 41 with a molecular weight of $40 \mathrm{kDa}$ (Pranamuda et al., 2001). This enzyme is able to degrade PLLA powder, casein, silk fibroin, succinyl-(L-alanyl-L-alanyl-L-alanine)$p$-nitroanilide (Suc-(Ala) 3 -pNA), but not polycaprolactone (PCL) nor polyhydroxybutyrate (PHB) with optimum $\mathrm{pH}$ and temperature of 6.0 and $37-45^{\circ} \mathrm{C}$, respectively. The enzyme production could be induced by silk powder from silkworm cocoons. These authors suggested that this purified enzyme is a protease with higher PLLA degrading activity than proteinase K.

Extracellular PLA depolymerase from Amycolatopsis sp. strain K104-1 was purified and characterized (Nakamura et al., 2001). The purified enzyme can degrade high-molecular-weight PLA in emulsion and solid film to lactic acid. This enzyme also degraded casein and fibrin but did not hydrolyze collagen type I, triolein, tributyrin, PHB, or PCL. It has a molecular weight of $24 \mathrm{kDa}$ with an optimum $\mathrm{pH}$ and temperature of 9.5 and $55-60^{\circ} \mathrm{C}$, respectively. The PLA degrading activity was inhibited by di-isopropyl fluorophosphates (DFP) and phenylmethanesulphonylfluoride (PMSF) which indicated that this purified enzyme was a serine type protease.

Three novel PLA-degrading enzymes namely PLAase I $(24.0 \mathrm{kDa})$, II $(19.5 \mathrm{kDa})$, and III $(18.0 \mathrm{kDa})$ were purified from A. orientalis ssp. orientalis (Li et al., 2008). The optimum $\mathrm{pH}$ was between 9.5-10.5 and temperature of $50-60^{\circ} \mathrm{C}$. These purified enzymes could degrade high molecular weight PLA film as well as casein. The PLA degrading activity of all three enzymes are higher than proteinase $\mathrm{K}$. They were identified as serine-like protease as their PLA degrading activities were strongly inhibited by serine protease inhibitors such as phenylmethylsulfonylfluoride and aprotinin. In addition, $\mathrm{N}$-terminal amino acid sequence of the protein was determined for the initial 17 residues (IIGGSNATSGPYAARLF). Seven N-terminal amino acid residues were $100 \%$ identical to fibrinolytic proteases from the earthworm while ten $\mathrm{N}$-terminal amino acid residues also revealed $80 \%$ identical to collagenolytic serine proteases from the hepatopancreas of the Kamchatka crab (Nakamura et al., 2001). 
From these results, purified depolymerase enzymes from PLA degrading Amycolatopsis strains are classified as serine protease which is specific to poly(L-lactic acid) (Matsuda et al., 2005; Tokiwa and Calabia, 2006; Kawai, 2010; Kawai et al., 2011; Wierckx et al., 2018).

Polylactic acid-degrading enzyme was also purified from Actinomadura keratinilytica T16-1 with molecular weight of $30 \mathrm{kDa}$ is able to degrade Suc-(Ala) $)_{3}-\mathrm{pNA}$, gelatin, PLA and casein but not PCL (Sukkhum et al., 2009b). The optimum pH and temperature were 10.0 and $70^{\circ} \mathrm{C}$, respectively. $\mathrm{N}$-terminal amino acid sequence of the purified enzyme was determined for the initial 15 residues (GYQNNPPSAGLDRAA). The hydrolyzing activity of the purified enzyme was inhibited by DFP, EDTA, and PMSF. This observation indicated that PLAdegrading enzyme produced from A. keratinilytica T16-1 is serine protease.

It has been reported that several actinobacteria exhibited a high level of PLLA-degrading activity when liquid culture medium were supplemented with poly(amino acids) inducers such as silk fibroin, elastin, gelatin, some peptides, and amino acids (Jarerat et al., 2004; Tokiwa and Calabia, 2006). For example, the PLLA-degrading enzyme activity of $A$. orientalis was increased from $0 \mathrm{U} / \mathrm{mL}$ to $450 \mathrm{U} / \mathrm{mL}$ in the medium supplemented with silk fibroin $(0.1 \% \mathrm{w} / \mathrm{v})$. Similarly, the supplement of $0.1 \%(\mathrm{w} / \mathrm{v})$ elastin was able to increase the PLA-degrading enzyme activity of Lentzea waywayandensis (formerly Saccharothrix waywayandensis) to $96 \mathrm{U} / \mathrm{mL}$ compared to culture control without inducer $(0 \mathrm{U} / \mathrm{mL})$ (Jarerat et al., 2004). Most inducers contain L-alanine which is similar to L-lactic acid subunits of PLA in the stereochemical position of chiral carbon (Qi et al., 2017). For example, the PLLAdegrading activity of Amycolatopsis sp. 41 was increased with the addition of silk powder into the culture medium from $8 \mathrm{mg}$ $\mathrm{TOC} / \mathrm{h} / \mathrm{mL}$ to $258 \mathrm{mg} \mathrm{TOC} / \mathrm{h} / \mathrm{mL}$ within 5 days (Pranamuda et al., 2001). PLLA-degrading enzymes of L. waywayandensis and Kibdelosporangium aridum were capable of degrading high molecular weight PLA film $\left(\bar{M}_{\mathrm{n}}: 3.4 \times 10^{5}\right)$ in a liquid medium containing $0.1 \%(\mathrm{w} / \mathrm{v})$ gelatin (Jarerat and Tokiwa, 2003; Jarerat et al., 2003).

The induction of PLA-degrading enzyme activities of two actinobacteria $L$. waywayandensis and $A$. orientalis was investigated using various poly(L-amino acids) (silk fibroin, gelatin, elastin, and keratin), peptides [(Ala $)_{2}$, Ala-Gly, $(\mathrm{Gly})_{2}$, $(\mathrm{Gly})_{3}$, Gly-Ala, and $(\mathrm{Gly})_{2}$-Ala] and amino acids (alanine, glycine, serine leucine, lysine, methionine, and valine) (Jarerat et al., 2004). The enzyme activities were varied between different strains and inducers. Silk fibroin was the best inducer for A. orientalis and elastin for L. waywayandensis. A clean biological recycling of PLA under mild condition $\left(40^{\circ} \mathrm{C}\right)$ using enzyme from A. orientalis $\mathrm{IFO} 12362^{\mathrm{T}}$ without organic solvent was also proposed (Jarerat et al., 2006). However, repolymerization of the degradation products was not carried out. Pseudonocardia alni AS4.1531 ${ }^{\mathrm{T}}$ was also reported to respond to $0.1 \%$ (w/v) gelatin inducer (Konkit et al., 2012). Similar result was observed in Pseudonocardia sp. RM423 in liquid medium with $0.3 \%(\mathrm{w} / \mathrm{v})$ gelatin as an inducer (Apinya et al., 2015). Strain RM423 was augmented into soil to assist the indigenous microorganisms with PLA degradation under both mesophilic and thermophilic conditions.

\section{DEVELOPMENT AND APPLICATION OF PLA DEGRADATION BY ACTINOBACTERIA}

Development of microbial-degradation process and formulation of PLA-degrading enzyme production media are needed as a sustainable technology for PLA waste management. Single culture, co-culture and microbial consortium were tried out to find the most effective biodegradable conditions. A comprehensive study on development of actinobacteria for PLA-degradation was reported in A. keratinilytica T16-1. Strain T16-1 is a novel actinobacteria isolated from Thai forest soil that showed the highest PLA-degrading activity at high temperature $\left(50^{\circ} \mathrm{C}\right)$ in liquid medium supplemented with PLA film as a carbon source (Sukkhum et al., 2009b, 2011). The fermentation processes for PLA degrading enzyme production by strain T16-1 has been well-studied. Biodegradation efficiency of strain T16-1 was investigated in shake flask culture. Factors affecting the enzyme production by A. keratinilytica T16-1 and medium optimization were investigated using response surface methodology (Sukkhum et al., 2009a). Poly(L-lactide)-degrading enzyme production by this strain was carried out in a $3 \mathrm{~L}$ airlift fermenter under the obtained optimum conditions. The optimal conditions of crude enzyme production were demonstrated as $0.43 \mathrm{vvm}$ aeration rate, $\mathrm{pH} 6.85$ and temperature of $46^{\circ} \mathrm{C}$. The obtained enzyme showed potential for PLA polymer recycle as L-lactic acid was found as the major degrading product. A yield of $800 \mathrm{mg} / \mathrm{L}$ L-lactic acid was obtained from the degradation of 4,000 $\mathrm{mg} / \mathrm{L} \mathrm{L}$-PLA powder at $60^{\circ} \mathrm{C}$ for $8 \mathrm{~h}$ (Sukkhum et al., 2012).

In addition, re-polymerization of PDLLA recycling process was evaluated by statistical methods based on central composite design (CCD) to develop new technologies for reducing plastic waste in the near future. Approximately $6,700 \mathrm{mg} / \mathrm{L}$ PLA powder was degraded by the crude enzyme under optimized conditions (Youngpreda et al., 2017). The degradation products were re-polymerized to form a PLA oligomer $\left(\bar{M}_{\mathrm{W}} 378 \mathrm{Da}\right)$. PLA-degrading enzyme activity of A. keratinilytica T16-1 was improved and reached $150 \mathrm{U} / \mathrm{mL}$ within $72 \mathrm{~h}$ in an up-scale 3L airlift fermenter (Panyachanakul et al., 2017). Furthermore, a suitable immobilization material and optimum medium for PDLLA-degrading enzyme production by A. keratinilytica T161 was investigated. A scrub pad gave the best performance, giving a crude enzyme activity of $30.03 \mathrm{U} / \mathrm{mL}$ in shake flask culture. PDLLA-degrading enzyme production of $766.33 \mathrm{U} / \mathrm{mL}$ with $15.97 \mathrm{U} / \mathrm{mL} \cdot \mathrm{h}$ of enzyme productivity were achieved with the optimum fermentation conditions of $0.25 \mathrm{vvm}$ aeration, $170 \mathrm{rpm}$ agitation and $45^{\circ} \mathrm{C}$ incubation temperature for $48 \mathrm{~h}$ in batch fermentation using $5 \mathrm{~L}$ stirrer fermenter. Recently, a scaleup for PLA degrading enzyme production by A. keratinilytica T16-1 in a 5L stirred tank bioreactor was carried out under batch condition (Panyachanakul et al., 2019). The best condition for PLA degradation was an agitation speed of $50 \mathrm{rpm}$ at $60^{\circ} \mathrm{C}$ under a controlled $\mathrm{pH}$ of 8.0. A potential method for 
TABLE 2 | General features of the genome of representative Amycolatopsis species.

\begin{tabular}{|c|c|c|c|c|c|c|}
\hline Species/Strains & Accession number & Genome size (bp) & Contigs & No. of coding sequences & tRNAs & $\mathbf{G}+\mathbf{C}$ content $(\%)$ \\
\hline Amycolatopsis alba DSM $44262^{\top}$ & KB913032 & $9,811,274$ & 1 & 9228 & 62 & 68.7 \\
\hline Amycolatopsis balhimycina DSM $44591^{\top}$ & AJ508239 & $10,858,503$ & 1 & 10190 & 65 & 70.8 \\
\hline Amycolatopsis japonica MG417-CF17 & CP008953 & $8,961,318$ & 1 & 8532 & 67 & 68.9 \\
\hline Amycolatopsis mediterranei U32 & CP002000 & $10,236,715$ & 1 & 9946 & 63 & 71.3 \\
\hline Amycolatopsis orientalis B-37 & СPCC200066 & $9,490,992$ & 1 & 8647 & 62 & 68.8 \\
\hline Amycolatopsis thailandensis $\mathrm{JCM} 16380^{\top}$ & NZ_NMQT00000000.1 & $9,348,263$ & 421 & 8990 & 67 & 68.8 \\
\hline Amycolatopsis tolypomycina DSM $44544^{\top}$ & NZ_FNSO00000000 & $10,363,431$ & 4 & 9780 & 64 & 71.7 \\
\hline
\end{tabular}

commercial PLA material degradation by this crude enzyme was also reported. However, lactic acid as degradation products showed inhibitory effect on PLA degradation process. PLA degradation efficiency could be enhanced using simultaneous PLA degradation and dialysis method. The maximum conversion efficiency (percentage of PLA that had been degraded to liberated lactic acid) of $89 \%$ was achieved after incubation for $72 \mathrm{~h}$ under optimum condition.

Polylactic acid recycling methods such as chemical hydrolysis and pyrolysis have been previously reported (Tsuji and Nakahara, 2002; Fan et al., 2003). However, biological recycling process is considered to be a more environmentally friendly and sustainable approach for PLA waste management. PLA degrading enzymes from actinobacteria such as A. orientalis (mesophilic condition) and A. keratinilytica T16-1 (thermophilic condition) are proved to be a potential candidate for biological recycling of PLA. Large scale fermentation of PLA degrading enzyme as exemplified in A. keratinilytica T16-1 is opened up the opportunity for a sustainable PLA waste management.

\section{GENOMIC INSIGHTS INTO PLA-DEGRADING ACTINOBACTERIA OF THE GENUS Amycolatopsis}

The genome sequences of six representatives Amycolatopsis strains, namely $A$. alba DSM 44262 (accession number: KB913032), A. balhimycina DSM $44591^{\mathrm{T}}$ (accession number: AJ508239), A. japonica MG417-CF17 (accession numbers: CP008953), A. orientalis B-37 (accession numbers: CPCC200066), A. mediterranei U32 (accession numbers: CP002000), and A. thailandensis JCM $16380^{\mathrm{T}}$ (accession numbers: NZ_NMQT00000000.1) were obtained from GenBank. These six phylogenetically closely related strains were selected based on whole genome comparison (data not shown) to test whether comparative genomics could provide useful information for the selection of PLA degrading strains. A. tolypomycina DSM $44544^{\mathrm{T}}$ (accession numbers: NZ_FNSO00000000) was also included in an analysis as a distantly related strain with the six Amycolatopsis strains. A. alba, A. orientalis, A. mediterranei, and A. thailandensis have been previously reported to have PLA degrading ability (Pranamuda and Tokiwa, 1999; Li et al., 2008; Chomchoei et al., 2011). All sequences were annotated using the Rapid
Annotation Subsystem Technology (RAST) server (Aziz et al., 2008). The distribution of PLA-degrading genes in the genomes was determined using the SEED server (Overbeek et al., 2014) with focus on genes encoding for protein degradation, serine endopeptidase and those regulating the effect of PLA-degrading activities. Genomic features of these six Amycolatopsis strains were listed in Table 2.

Serine proteases/serine endopeptidases (EC 3.4.21.-) are enzymes responsible for PLA degradation. It was purified and characterized from PLA-degrading actinobacteria, Amycolatopsis sp. (Pranamuda et al., 2001; Li et al., 2008). Comparative genomics reveal that serine endopeptidase related genes such as sspA and blaSE are present in protein degradation subsystem category of all representatives Amycolatopsis species (Supplementary Table 1). However, there is no report on PLA degrading activities of either A. balhimycina DSM $44591^{\mathrm{T}}$ or A. japonica MG417-CF17. It is reasonable to believe that these two species will have PLA degrading property similar to their phylogenetically related neighbors. Interestingly, these genes encoding for PLA degrading enzymes are also present in genomes of A. tolypomycina DSM $44544^{\mathrm{T}}$ which is distantly related to the six representative strains. From this small set of comparison, it seems that these genes related to PLA degradation are conserved within the members of the genus Amycolatopsis. We believe that this genomic analysis will provides a powerful tool for exploiting genetics potential of actinobacteria for PLA degradation.

\section{CONCLUSION AND FUTURE PERSPECTIVES}

This mini-review provides evidence to support the view that actinobacteria are potential PLA degrading microorganisms. Several members of actinobacteria are able to degrade poly(lactic acid) bioplastics either under laboratory conditions or under field trials (Table 1). Selective isolation and cultivation of PLA degrading actinobacteria under laboratory conditions is proving to be a challenge. There is still a room for improvement in selective isolation procedures and strategies to target specific actinobacterial taxa of interest. A sound taxonomic data will provide a ground for an improved isolation and cultivation for PLA degrading actinobacteria. Comparative genomics offer a 
tool for screening of potential PLA degrading actinobacteria as exemplified in this study. The accumulation of highquality whole genome data provides a useful information to support the search for novel actinobacterial strains with PLA degrading ability. Actinobacteria are well known for their ability to produce bioactive compounds. However, their potential as PLA degraders is just becoming apparent. PLA degrading actinobacteria such as Amycolatopsis and Actinomadura have shown promise which deserves research attention as market demand for PLA plastics are continuously on the rise.

\section{AUTHOR CONTRIBUTIONS}

NB contributed to the data for diversity of PLA degrading actinobacteria, their enzyme production and inducers, whole genome analysis and Tables $\mathbf{1}, \mathbf{2}$. WP-A conceived the idea, wrote and revised the manuscript.

\section{REFERENCES}

Ahmed, T., Shahid, M., Azeem, F., Rasul, I., Shah, A. A., Noman, M., et al. (2018). Biodegradation of plastics: current scenario and future prospects for environmental safety. Environ. Sci. Pollut. Res. 25, 7287-7298. doi: 10.1007/ s11356-018-1234-9

Alshehrei, F. (2017). Biodegradation of synthetic and natural plastic by microorganisms. J. Appl. Environ. Microbiol. 5, 8-19. doi: 10.12691/jaem-5-1-2

Apinya, T., Sombatsompop, N., and Prapagdee, B. (2015). Selection of a Pseudonocardia sp. RM423 that accelerates the biodegradation of poly(lactic) acid in submerged cultures and in soil microcosms. Int. Biodeterior. Biodegrad. 99, 23-30. doi: 10.1016/j.ibiod.2015.01.001

Aziz, R. K., Bartels, D., Best, A. A., DeJongh, M., Disz, T., Edwards, R. A., et al. (2008). The RAST server: rapid annotations using subsystems technology. BMC Genom. 9:75. doi: 10.1186/1471-2164-9-75

Banerjee, A., Chatterjee, K., and Madras, G. (2014). Enzymatic degradation of polymers: a brief review. Mater. Sci. Technol. 30, 567-573. doi: 10.1179/ 1743284713Y.0000000503

Bubpachat, T., Sombatsompop, N., and Prapagdee, B. (2018). Isolation and role of polylactic acid-degrading bacteria on degrading enzymes productions and PLA biodegradability at mesophilic conditions. Polym. Degrad. Stab. 152, 75-85. doi: 10.1016/j.polymdegradstab.2018.03.023

Busarakam, K., Brown, R., Bull, A. T., Tan, G. Y., Zucchi, T. D., da Silva, L. J., et al. (2016). Classification of thermophilic actinobacteria isolated from arid desert soils, including the description of Amycolatopsis deserti sp. nov. Antonie van Leeuwenhoek 109, 319-334. doi: 10.1007/s10482-015-0635-8

Calabia, B. P., Tokiwa, Y., Ugwu, C. U., and Aiba, S. (2010). "Chapter 25 biodegradation," in Poly(lactic acid): Synthesis, Structures, Properties, Processing, and Applications, eds R. Auras, L. T. Lim, S. E. M. Selke, and H. Tsuji, (New Jersey: Wiley Publishing), 423-430.

Carosio, F., Colonna, S., Fina, A., Rydzek, G., Hemmerlé, J., Jierry, L., et al. (2014). Efficient gas and water vapor barrier properties of thin poly (lactic acid) packaging films: functionalization with moisture resistant Nafion and clay multilayers. Chem. Mater. 26, 5459-5466. doi: 10.1021/cm501359e

Chomchoei, A., Pathom-aree, W., Yogota, T., Kanonguch, C., and Lumyong, S. (2011). Amycolatopsis thailandensis sp. nov., a poly(L-lactic acid)-degrading actinomycete, isolated from soil. Int. J. Syst. Evol. Microbiol. 61, 839-843. doi: 10.1099/ijs.0.023564-0

de Wilde, B. (2009). Anaerobic Digestion, Vol 4. Mönchengladbach: Bioplastics Magazine.

Fan, Y., Nishida, H., Hoshihara, S., Shirai, Y., Tokiwa, Y., and Endo, T. (2003). Pyrolysis kinetics of poly(L-lactide) with carboxyl and calcium salt end

\section{FUNDING}

A scholarship from the Thailand Graduate Institute of Science and Technology (TGIST), National Science and Technology Development Agency (NSTDA) (Grant No. SCA-CO-2562-9844$\mathrm{TH})$ is gratefully acknowledged.

\section{ACKNOWLEDGMENTS}

NB is grateful to the Graduate School, Chiang Mai University for TA/RA scholarship for the academic year 2018-2019.

\section{SUPPLEMENTARY MATERIAL}

The Supplementary Material for this article can be found online at: https://www.frontiersin.org/articles/10.3389/fmicb. 2019.02834/full\#supplementary-material

structures. Polym. Degrad. Stabil. 79, 547-562. doi: 10.1016/S0141-3910(02) 00374-9

Farah, S., Anderson, D. G., and Langer, R. (2016). Physical and mechanical properties of PLA, and their functions in widespread applications-a comprehensive review. Adv. Drug Deliv. Rev. 107, 367-392. doi: 10.1016/j.addr. 2016.06.012

Farrington, D. W., Davies, J. L. S., and Blackburn, R. S. (2005). "Chapter 6: poly(lactic acid) fibers," in Biodegradable and Sustainable Fibres, ed. R. S. Blackburn, (Amsterdam: Elsevier), 191-220.

Garlotta, D. (2001). A literature review of poly(lactic acid). J. Polym. Environ. 9, 63-84. doi: 10.1023/A:1020200822435

Geyer, R., Jambeck, J. R., and Law, K. L. (2017). Production, use, and fate of all plastics ever made. Sci. Adv. 3, e1700782. doi: 10.1126/sciadv.1700782

Hajighasemi, M., Nocek, B. P., Tchigvintsev, A., Brown, G., Flick, R., Xu, X., et al. (2016). Biochemical and structural insights into enzymatic depolymerization of polylactic acid and other polyesters by microbial carboxylesterases. Biomacromolecules 17, 2027-2039. doi: 10.1021/acs.biomac.6b00223

Hedstrom, L. (2002). Serine protease mechanism and specificity. Chem. Rev. 102, 4501-4524. doi: 10.1021/cr000033x

Hu, X., Thumarat, U., Zhang, X., Tang, M., and Kawai, F. (2010). Diversity of polyester-degrading bacteria in compost and molecular analysis of a thermoactive esterase from Thermobifida alba AHK119. Appl. Microbiol. Biotechnol. 87, 771-779. doi: 10.1007/s00253-010-2555-x

Husárová, L., Pekařová, S., Stloukal, P., Kucharzcyk, P., Verney, V., Commereuc, S., et al. (2014). Identification of important abiotic and biotic factors in the biodegradation of poly (L-lactic acid). Int. J. Biol. Macromol. 71, 155-162. doi: 10.1016/j.ijbiomac.2014.04.050

Idris, H., Nouioui, I., Pathom-aree, W., Asenjo, J. A., and Goodfellow, M. (2018). Amycolatopsis vastitatis sp. nov., an isolate from a high altitude subsurface soil on Cerro Chajnantor, northern Chile. Antonie van Leeuwenhoek 111, 1523-1533. doi: 10.1007/s10482-018-1039-3

Ikada, Y., and Tsuji, H. (2000). Biodegradable polyesters for medical and ecological applications. Macromol. Rapid Commun. 21, 117-132. doi: 10.1002/(SICI)15213927(20000201)21:3<117::AID-MARC117>3.0.CO;2-X

Ikura, Y., and Kudo, T. (1999). Isolation of a microorganism capable of degrading poly-(L-lactide). J. Gen. Appl. Microbiol. 45, 247-251. doi: 10.2323/jgam.45.247

Jalil, R. (1990). Biodegradable poly(lactic acid) and poly(lactide-co-glycolide) polymers in sustained drug delivery. Drug Dev. Ind. Pharm. 16, 2353-2367. doi: 10.3109/03639049009058535

Jarerat, A., Pranamuda, H., and Tokiwa, Y. (2002). Poly(L-lactide)-degrading activity in various actinomycetes. Macromol. Biosci. 2, 420-428. doi: 10.1002/ mabi.200290001 
Jarerat, A., and Tokiwa, Y. (2001). Degradation of poly (L-lactide) by a fungus. Macromol. Biosci. 1, 136-140. doi: 10.1002/1616-5195(20010601)1:4<136::aidmabi136>3.0.co;2-3

Jarerat, A., and Tokiwa, Y. (2003). Poly(L-lactide) degradation by Saccharothrix waywayandensis. Biotechnol. Lett. 25, 401-404. doi: 10.1023/A:1022450431193

Jarerat, A., Tokiwa, Y., and Tanaka, H. (2003). Poly (L-lactide) degradation by Kibdelosporangium aridum. Biotechnol. Lett. 25, 2035-2038. doi: 10.1023/B: BILE.0000004398.38799.29

Jarerat, A., Tokiwa, Y., and Tanaka, H. (2004). Microbial poly(L-lactide)-degrading enzyme induced by amino acids, peptides, and poly(L-amino acids). J. Polym. Environ. 12, 139-146. doi: 10.1023/B:JOOE.0000038545.69235.f2

Jarerat, A., Tokiwa, Y., and Tanaka, H. (2006). Production of poly(L-lactide)degrading enzyme by Amycolatopsis orientalis for biological recycling of poly(Llactide). Appl. Microbiol. Biotechnol. 72, 726-731. doi: 10.1007/s00253-0060343-4

Karamanlioglu, M., Preziosi, R., and Robson, G. D. (2017). Abiotic and biotic environmental degradation of the bioplastic polymer poly(lactic acid): a review. Polym. Degrad. Stab. 137, 122-130. doi: 10.1016/j.polymdegradstab.2017.01.009

Karan, H., Funk, C., Grabert, M., Oey, M., and Hankamer, B. (2019). Green bioplastics as part of a circular bioeconomy. Trends Plant Sci. 24, 237-249. doi: 10.1016/j.tplants.2018.11.010

Kawai, F. (2010). "Polylactic acid (PLA)-degrading microorganisms and PLA depolymerases," in Green Polymer Chemistry: Biocatalysis and Biomaterials, eds H. N. Cheng and R. A. Gross (Washington, DC: American Chemical Society), 405-414. doi: 10.1021/bk-2010-1043.ch027

Kawai, F., Nakadai, K., Nishioka, E., Nakajima, H., Ohara, H., Masaki, K., et al. (2011). Different enantioselectivity of two types of poly (lactic acid) depolymerases toward poly (L-lactic acid) and poly (D-lactic acid). Polym. Degrad. Stab. 96, 1342-1348. doi: 10.1016/j.polymdegradstab.2011.03.022

Kim, M. N., Kim, W. G., Weon, H. Y., and Lee, S. H. (2008). Poly(L-lactide)degrading activity of a newly isolated bacterium. J. Appl. Polym. Sci. 109, 234-239. doi: 10.1002/app.26658

Kitadokoro, K., Kakara, M., Matsui, S., Osokoshi, R., Thumarat, U., Kawai, F., et al. (2019). Structural insights into the unique polylactate-degrading mechanism of Thermobifida alba cutinase. FEBS J. 286, 2087-2098. doi: 10.1111/febs.14781

Konkit, M., Jarerat, A., Kanonguch, C., Lumyong, S., and Pathom-aree, W. (2012). Poly (lactide) degradation by Pseudonocardia alni AS4.1531 ${ }^{\mathrm{T}}$. Chiang Mai J. Sci. 39, 128-132.

Li, F., Wang, S., Liu, W., and Chen, G. (2008). Purification and characterization of poly(L-lactic acid)-degrading enzymes from Amycolatopsis orientalis ssp. orientalis. FEMS Microbiol. Lett. 282, 52-58. doi: 10.1111/j.1574-6968.2008. 01109.x

Lim, H.-A., Raku, T., and Tokiwa, Y. (2005). Hydrolysis of polyesters by serine proteases. Biotechnol. Lett. 27, 459-464. doi: 10.1007/s10529-005-2217-8

Matsuda, E., Abe, N., Tamakawa, H., Kaneko, J., and Kamio, Y. (2005). Gene cloning and molecular characterization of an extracellular poly (L-lactic acid) depolymerase from Amycolatopsis sp. strain K104-1. J. Biotechnol. 187, 73337340. doi: 10.1128/JB.187.21.7333-7340.2005

Mekonnen, T., Mussone, P., Khalil, H., and Bressler, D. (2013). Progress in bio-based plastics and plasticizing modifications. J. Mater. Chem. A. 1, 1337913398. doi: 10.1039/C3TA12555F

Nair, N. R., Nampoothiri, K. M., and Pandey, A. (2012). Preparation of poly(L-lactide) blends and biodegradation by Lentzea waywayandensis. Biotechnol. Lett. 34, 2031-2035. doi: 10.1007/s10529-012-1005-5

Nakamura, K., Tomita, T., Abe, N., and Kamio, Y. (2001). Purification and characterization of an extracellular poly(L-lactic acid) depolymerase from a soil isolate, Amycolatopsis sp. strain K104-1. Appl. Environ. Microbiol. 67, 345-353. doi: 10.1128/AEM.67.1.345-353.2001

Nishida, H., and Tokiwa, Y. (1993). Distribution of poly ( $\beta$-hydroxybutyrate) and poly ( $\varepsilon$-caprolactone) aerobic degrading microorganisms in different environments. J. Environ. Polym. Degrad. 1, 227-233. doi: 10.1007/BF01458031

Overbeek, R., Olson, R., Pusch, G. D., Olsen, G. J., Davis, J. J., Disz, T., et al. (2014). The SEED and the rapid annotation of microbial genomes using subsystems technology (RAST). Nucleic Acids Res. 42, D206-D214.

Panyachanakul, T., Kitpreechavanich, V., Tokuyama, S., and Krajangsang, S. (2017). Poly(DL-lactide)-degrading enzyme production by immobilized Actinomadura keratinilytica strain T16-1 in a 5-L fermenter under various fermentation processes. Electron. J. Biotechnol. 30, 71-76. doi: 10.1016/j.ejbt. 2017.09.001

Panyachanakul, T., Sorachart, B., Lumyong, S., Lorliam, W., Kitpreechavanich, V., and Krajangsang, S. (2019). Development of biodegradation process for poly(DL-lactic acid) degradation by crude enzyme produced by Actinomadura keratinilytica strain T16-1. Electron. J. Biotechnol. 40, 52-57. doi: 10.1016/j.ejbt. 2019.04.005

Penkhrue, W., Khanongnuch, C., Masaki, K., Pathom-aree, W., Punyodom, W., and Lumyong, S. (2015). Isolation and screening of biopolymer-degrading microorganisms from northern Thailand. World J. Microbiol. Biotechnol. 31, 1431-1442. doi: 10.1007/s11274-015-1895-1

Penkhrue, W., Sujarit, K., Kudo, T., Ohkuma, M., Masaki, K., Aizawa, T., et al. (2018). Amycolatopsis oliviviridis sp.nov., a novel polylactic acid (PLA)bioplastic degrading actinomycete isolated from paddy soil. Int. J. Syst. Evol. Microbiol. 68, 1448-1454. doi: 10.1099/ijsem.0.002682

Pham, V. H. T., and Kim, J. (2012). Cultivation of unculturable soil bacteria. Trend Biotechnol. 30, 475-484. doi: 10.1016/j.tibtech.2012.05.007

Pranamuda, H., and Tokiwa, Y. (1999). Degradation of poly (L-lactide) by strains belonging to genus Amycolatopsis. Biotechnol. Lett. 21, 901-905. doi: 10.1023/A: 1005547326434

Pranamuda, H., Tokiwa, Y., and Tanaka, H. (1997). Polylactide degradation by an Amycolatopsis sp. Appl. Environ. Microbiol. 63, 1637-1640.

Pranamuda, H., Tsuchii, A., and Tokiwa, Y. (2001). Poly (L-lactide)-degrading enzyme produced by Amycolatopsis sp. Macromol. Biosci. 1, 25-29. doi: 10.1002/ 1616-5195(200101)

Qi, X., Ren, Y., and Wang, X. (2017). New advances in the biodegradation of poly(lactic) acid. Int. Biodeter. Biodegr. 117, 215-223. doi: 10.1016/j.ibiod.2017. 01.010

Sangal, V., Goodfellow, M., Blom, J., Tan, G. Y. A., Klenk, H.-P., and Sutcliffe, I. C. (2018). Revisiting the taxonomic status of the biomedically and industrially important genus Amycolatopsis, using a phylogenomic approach. Front. Microbiol. 9:2281. doi: 10.3389/fmicb.2018.02281

Sangwan, P., Way, C., and Wu, D.-Y. (2009). New insight into biodegradation of polylactide (PLA)/clay nanocomposites using molecular ecological techniques. Macromol. Biosci. 9, 677-686. doi: 10.1002/mabi.2008 00276

Sangwan, P., and Wu, D. Y. (2008). New insight into polylactide biodegradation from molecular ecological techniques. Macromol. Biosci. 8, 304-315. doi: 10. 1002/mabi.200700317

Scarfato, P., Maio, L. D., and Incarnato, L. (2015). Recent advances and migration issues in biodegradable polymers from renewable sources for food packaging. J. Appl. Polym. Sci. 132, 42597. doi: 10.1002/app.42597

Song, J., Kay, M., and Coles, R. (2011). "Chapter 11: bioplastics," in Food and Beverage Packaging Technology, eds R. Coles, and M. Kirwan, (Chichester: Blackwell Publishing), 295-319.

Song, J. H., Murphy, R. J., Narayan, R., and Davies, G. (2009). Biodegradable and compostable alternatives to conventional plastics. Philos. Trans. R. Soc. Lond. B. Biol. Sci. 364, 2127-2139. doi: 10.1098/rstb.2008.0289

Sriyapai, P., Chansiri, K., and Sriyapai, T. (2018). Isolation and characterization of polyester-based plastics-degrading bacteria from compost soils. Microbiology 87, 290-300. doi: 10.1134/S0026261718020157

Stewart, E. J. (2012). Growing unculturable bacteria. J. Bacteriol. 194, 4151-4160. doi: 10.1128/JB.00345-12

Sukkhum, S., Shinji, T., and Kitpreechavanich, V. (2012). Poly(L-lactide)degrading enzyme production by Actinomadura keratinilytica T16-1 in $3 \mathrm{~L}$ airlift bioreactor and its degradation ability for biological recycle. J. Microbiol. Biotechnol. 22, 92-99. doi: 10.4014/jmb.1105. 05016

Sukkhum, S., Tokuyama, S., and Kitpreechavanich, V. (2009a). Development of fermentation process for PLA-degrading enzyme production by a new thermophilic Actinomadura sp. T16-1. Biotechnol. Bioproc. Eng. 14, 302-306. doi: 10.1007/s12257-008-0207-0

Sukkhum, S., Tokuyama, S., Tarmura, T., and Kitpreechavanich, V. (2009b). A novel poly (L-lactide) degrading actinomycetes isolated from Thai forest soil, phylogenic relationship and the enzyme characterization. J. Gen. Appl. Microbiol. 55, 459-467. doi: 10.2323/jgam.55.459

Sukkhum, S., Tokuyama, S., Kongsaeree, P., Tamura, T., Ishida, Y., and Kitpreechavanich, V. (2011). A novel poly (L-lactide) degrading thermophilic 
actinomycetes, Actinomadura keratinilytica strain T16-1 and pla sequencing. Afr. J. Microbiol. Res. 5, 2575-2582. doi: 10.5897/AJMR10.722

Suyama, T., Tokiwa, Y., Ouichanpagdee, P., Kanagawa, T., and Kamagata, Y. (1998). Phylogenetic affiliation of soil bacteria that degrade aliphatic polyesters available commercially as biodegradable plastics. Appl. Environ. Microbiol. 64, 5008-5011.

Szumigaj, J., Żakowska, Z., Klimek, L., Rosicka-Kaczmarek, J., and Bartkowiak, A. (2008). Assessment of polylactide foil degradation as a result of filamentous fungi activity. Polish J. Environ. Stud. 17, 335-341.

Tan, G. Y. A., and Goodfellow, M. (2015). "Amycolatopsis," in Bergey's Manual of Systematic Bacteriology, ed. W. B. Whitman, (Hoboken, NJ: JohnWiley \& Sons), $1-40$.

Tokiwa, Y., and Calabia, B. P. (2006). Biodegradability and biodegradation of poly(lactide). Appl. Microbiol. Biotechnol. 72, 244-251. doi: 10.1007/s00253006-0488-481

Tokiwa, Y., Calabia, B. P., Ugwu, C. U., and Aiba, S. (2009). Biodegradability of plastics. Int. J. Mol. Sci. 10, 3722-3742. doi: 10.3390/ijms10093722

Tokiwa, Y., and Jarerat, A. (2004). Biodegradation of poly(L-lactide). Biotechnol. Lett. 26, 771-777. doi: 10.1023/B:BILE.0000025927.31028.e3

Tokiwa, Y., Konno, M., and Nishida, H. (1999). Isolation of silk degrading microorganisms and its poly(L-lactide) degradability. Chem. Lett. 28, 355-356. doi: 10.1246/cl.1999

Torres, A., Li, S. M., Roussos, S., and Vert, M. (1996). Screening of microorganisms for biodegradation of poly(lactic acid) and lactic acid-containing polymers. Appl. Environ. Microbiol. 62, 2393-2397.

Tsuji, H., and Nakahara, K. (2002). Poly(L-lactide). IX. Hydrolysis in acid media. J. Appl. Polym. Sci. 86, 186-194. doi: 10.1002/app.10813

Vink, E. T. H., Rábago, K., Glassner, D. A., Springs, B., O'Connor, R. P., Kolstad, J., et al. (2004). The sustainability of NatureWorks ${ }^{\mathrm{TM}}$ polylactide polymers and Ingeo ${ }^{\mathrm{TM}}$ polylactide fibers: an update of the future. Macromol. Biosci. 4, 551-564. doi: 10.1002/mabi.200400023
Vink, E. T. H., Rab́ago, K. R., Glassner, D. A., and Gruber, P. R. (2003). Applications of life cycle assessment to NatureWorks ${ }^{\text {TM }}$ polylactide (PLA) production. Polym. Degrad. Stab. 80, 403-419. doi: 10.1016/S0141-3910(02)00 372-5

Wierckx, N., Narancic, T., Eberlein, C., Wei, R., Drzyzga, O., Magnin, A., et al. (2018). "Plastic biodegradation: challenges and opportunities," in Consequences of Microbial Interactions with Hydrocarbons, Oils, and Lipids: Biodegradation and Bioremediation, ed. R. Steffan, (Berlin: Springer International Publishing), 1-29. doi: 10.1007/978-3-319-44535-9_23-1

Williams, D. F. (1981). Enzymic hydrolysis of polylactic acid. Eng. Med. 10, 5-7. doi: 10.1243/EMED-JOUR-1981-010-004-02

Yottakot, S., and Leelavatcharamas, V. (2019). Isolation and optimization of polylactic acid (PLA)-packaging-degrading actinomycete for PLA-packaging degradation. Pertanika J. Trop. Agric. Sci. 42, $1111-1129$.

Youngpreda, A., Panyachanakul, T., Kitpreechavanich, V., Sirisansaneeyakul, S., Suksamrarn, S., Tokuyama, S., et al. (2017). Optimization of poly(DL-lactic acid) degradation and evaluation of biological repolymerization. J. Polym. Environ. 25, 1131-1139. doi: 10.1007/s10924-0160885-1

Conflict of Interest: The authors declare that the research was conducted in the absence of any commercial or financial relationships that could be construed as a potential conflict of interest.

Copyright (C) 2019 Butbunchu and Pathom-Aree. This is an open-access article distributed under the terms of the Creative Commons Attribution License (CC BY). The use, distribution or reproduction in other forums is permitted, provided the original author(s) and the copyright owner(s) are credited and that the original publication in this journal is cited, in accordance with accepted academic practice. No use, distribution or reproduction is permitted which does not comply with these terms. 